\title{
Increasing Global Perspective in the Classroom
}

\author{
Adrian James \\ Park University \\ Greg Moore \\ Park University
}

This study investigated gains in global perspective after students completed an in-class, experiential learning activity, designed for cultural awareness. Students were enrolled in a 200-level, one credit-hour, seminar in business at (removed) in the management department. Significant gains were found for the cognitive and interpersonal domains on the global perspective inventory (GPI). This asserts that even short, in-class, activities can increase global perspective.

Keywords: global perspective, cultural awareness, higher education

\section{INTRODUCTION}

As noted by Braskamp, Braskamp, and Glass (2015), institutions of higher education must create environments which "optimally and effectively influence and foster global learning" (p. 6). Trends in recent years have caused an increase in globalization, which is creating an environment for institutions of higher learning to prepare "globally competent citizens" (Montgomery \& Arensdorf, 2012). Institutions of higher learning must prepare students to move beyond an ethnocentric view of the world focused on their local community, and expand their view towards one of global citizenship.

In the context of global citizenship, educational institutions, and specifically educators, should be preparing students for a competitive global market in which students have a global view of their citizenship and work to contribute to the improvement of the world's economy and society. As noted by AACSB International (2017), educators should prepare students through improved understanding between nations, businesses and individuals. In addition, AACSB International noted that a focus on diverse perspectives or ideas encourages a learning environment in which students have a more robust learning environment which supports mutual respect across cultures.

Given the increasing complexity of issues facing businesses and non-business entities, education of students should focus on development of a global perspective which is a more inclusive and just view of the world. While universities have instituted and utilized various tools for developing a student's global perspective through diversity education, multicultural curricula, and study abroad programs, evidence has been limited related to these programs effectiveness with increasing a student's global perspective (Musil, 2006). Using data from the Global Perspective Inventory (GPI), educators can measure a student's ability to adopt a more global perspective through an examination attributes of global learning (Braskamp et al., 2015). Specifically, the GPI is used to measure a student's global perspective along three dimensions: 
cognitive, intrapersonal, and interpersonal dimensions of global learning. Using the GPI national survey as a measure of a student's global perspective, could coursework improve a student's global perspective as measured using the GPI?

\section{Hypotheses}

The purpose of this study is to determine if global perspective can be improved with an experiential learning, cultural awareness, activity in the classroom. The following hypotheses were tested.

Hypothesis 1. Participation in a cultural awareness activity will increase one's knowing of what is important to know and value when judging cultural contexts.

Hypothesis 2. Participation in a cultural awareness activity will increase understanding and awareness of various cultures.

Hypothesis 3. Participation in a cultural awareness activity will increase level of openness to those who live life differently than their own cultural norms.

\section{LITERATURE REVIEW}

Global citizenship has been defined by Barber (2002) as individuals who are aware of the interdependence of both the local and global community. Within businesses, leaders must be prepared to provide solutions to social issues, not only at a local level, but on a global scale as well. Higher education programs have a responsibility to educate their student population as it relates to being a globally competent citizen (Montgomery \& Arensdorf, 2012). The mandate for students to be competent global citizens arises from the need for competent global leaders in organizations around the world.

The global economy is being impacted by many factors including an expanding global economy, international businesses, and impacts on business and trade due to technological advancements (Jokinen, 2005; Earnest, 2003). For individuals to be successful in the global market, skills focusing on cultural sensitivity, teamwork, and communication must be developed (Chhokar, Brodbeck, \& House, 2007; Earnest, 2003; Salisbury, Umbach, Paulsen, \& Pascarella 2009). Cohen (2010) expands upon this and states that for employees to be successful in the global market, they must develop a "global mind-set". A global mind-set is developed through an individual understanding of local and cultural differences, flexibility in their ability to cross cultures and the changing environmental contexts, and having an "openness to and awareness of diversity across cultures and markets with a willingness to synthesize across this diversity" (Cohen, 2010).

\section{The Need to Increase Global Perspective}

During undergraduate studies, colleges and universities have a role in fostering a student's global perspective (Association of American Colleges and Universities, 2007). A global perspective relies upon competencies such a valuing teamwork, managing complexity, managing adaptability, diversity, and seeking change (Rhinesmith, 1996). Global leadership was defined by Marquardt and Berger (2000) as individuals who are visionary, possess a concern for ethics, team builder, and being servant minded.

A study of human resource managers from international organizations identified global considerations for decision making as one of the top attributes for a business leader (Goldsmith, Greenberg, Robertson, \& Hu-Chan, 2003). Chhokar et al., (2008) identified value based, team oriented, participative as critical dimensions for global leaders in the comprehensive GLOBE study. Jokinen (2005) identified three competencies for global leadership: self-awareness, inquisitiveness, and engagement in personal transformation.

Within the global economy, employers are seeking individuals who demonstrate leadership skills which can be applied in a multiple of contexts (Casner-Lotto \& Barrington, 2006). According to the employers surveyed, "oral communications, teamwork/collaboration, professionalism/work ethic, written 
communications, and critical thinking/problem-solving were the top five applied skills desired in rank order" (Casner-Lotto \& Barrington, 2006, p.23). Within the global economy, future leaders must be prepared to engage in a more complex, diverse, and rapidly changing environment (Earnest, 2003). Skills focused on the global market and business can be learned utilizing both in-classroom experience, and study abroad opportunities (Montgomery \& Arensdorf, 2012). Through the incorporation of classroom and study abroad opportunities, universities can develop curriculum to foster a global perspective of future business leaders to remain competitive in this global economy.

Curriculum should focus on leadership programs which stress the skills necessary in the contemporary business organization. Courses must adapt to the shifting needs of not only society, but the workplace setting in a global context (Mendenhall, Osland, Bird, Oddou, \& Maznevski, 2008). Within the university context, coursework should combine the theory and practice to create a comprehensive curriculum. Courses should provide not only the leadership competencies, but also the opportunity to experience leadership through various perspectives (Riggio, Ciulla, \& Sorenson, 2003). Students who experience study abroad opportunities have the opportunity to become immersed in a new culture and engage in conversations related to differences (Montgomery \& Arensdorf, 2012). Incorporation of study abroad with innovative classroom opportunities create opportunities for students to experience differences in language, culture and leadership styles (Moore, Boyd, Rosser, \& Elbert, 2009).

\section{Global Perspective Domains and Scales}

The Global Perspectives Inventory (GPI) which was designed to measure a student's journey to becoming global citizens in a complex world (Merrill, Braskamp, \& Braskamp, 2012). The GPI has been used by over 120,000 students, faculty, and staff. It has been determined to be a valid and reliable instrument to measure global perspective (Braskamp, Braskamp, \& Engberg, 2014).

The GPI measures a holistic view of a person's understanding of global society (cognitive domain), an awareness of their identity in relation to other cultures (intrapersonal domain), and the degree of their interaction with other cultures (interpersonal domain). Each of these domains is measured by two scales.

As previously stated, the Global Perspectives Index was designed to measure an individual's cognitive, intrapersonal, and interpersonal domains. The Cognitive domain is focused on the scales of Knowing and Knowledge. Knowing measures the cultural context for identifying and determining what is important to know and value, and Knowledge measures the awareness of various cultures and the impact on the global society (Braskamp et al., 2014). The Intrapersonal domain's two scales are Identity and Affect. Identity is the awareness of unique identity, and Affect focuses on respect and acceptance of other cultures which differ from one's own (Braskamp et al., 2014). Finally, the Interpersonal domain scales are Social Responsibility and Social Interactions. Social Responsibility measures the view of our interdependence and our concern for others in society, and Social Interactions measures one's engagement with others who may be different from ourselves and our sensitivity to other cultures when living in a pluralistic society (Braskamp et al., 2014).

\section{BARNGA}

BARNGA is an experiential learning game that exposes cross-cultural challenges. It is a card game that simulates the complications associated with intercultural situations. Those playing the game soon realize that even small changes can have a big impact (Thiagarajan \& Thiagarajan, 2006). At the start of the game, players are given instruction cards. The instructions look the same but have small differences. F or example, on one set of instructions, the ace is high, but on another it is low. On one, the winner gathers up the cards of each hand and another the loser does it. Up to 40 players can play during this activity.

For this study, students were put in four groups of four. They read the instructions individually for three minutes and play in their group of four for 5 minutes. Instruction cards are taken away once practice play begins. Players are not allowed to talk during the game. Once the groups have played for five minutes,

tournament play begins. The winners of each group go to one table, losers to another, etc. They are still prohibited from speaking. 
This is where the complications arise. Since the instruction cards were taken away so quickly, there are assumptions that some have remembered the rules wrong, and thus, playing by the wrong rules. With the "no talking" rule, players must navigate the differences. The facilitator can encourage writing and hand gestures to solve any issues. Once a couple of rounds are played, the activity is debriefed with discussion questions. This study used six questions: 1) How do you feel, and what made you feel that way? 2) What happened during the simulation? 3) What were your greatest successes and frustrations? 4) What did you learn? 5) How is this game like real life? 6) How does this relate to culture?

\section{DATA AND METHODOLOGY}

\section{Participants}

Participants were students enrolled in a 200-level business course in the fall 2017 semester at (removed). There were 152 students enrolled in five sections of the course. There were 118 who attended the day of the activity. Of the 118, there were 45 useable responses. Participants who did not complete the activity were not included in the analysis. Further, only students whose data could be matched for the pre and post surveys were not included in the analysis.

There were 24 females and 21 males included in the analysis. They were $52.30 \%(n=24)$ sophomores, $28.90 \%(n=13)$ juniors and $17.80 \%(n=8)$ seniors $)$. Ages ranged from 18 to 58 with $70.45 \%(n=31)$ of them age 19 to 22 .

\section{Procedure and Analysis}

Students were asked to complete the GPI the week before the cultural activity and, once again, the week after the cultural activity. Students were asked to provide their university identification number so that pre and post survey scores could be matched. Paired-sample t-tests were used to analyze if differences in pre and post scores occurred.

\section{RESULTS}

\section{Hypothesis Testing}

Hypothesis 1 tested the increase in one's knowing of what is important to know and value when judging cultural contexts. Results were determined using the knowing scale of the GPI. A significant difference was not found.

Hypothesis 2 tested the increase in cultural awareness after exposure to the BARNGA activity. Results were determined using the knowledge scale of the GPI. A significant increase was found. Results are shown in Table 1.

TABLE 1

\section{T-TEST RESULTS FOR PRE AND POST-TEST OF KNOWING AND KNOWLEDGE SCALES}

\begin{tabular}{lcccccr}
\hline Variable & Pre-test & Post-test & & & \\
& Mean (SD) & Mean (SD) & \multicolumn{1}{c}{$t$} & $d f$ & \multicolumn{1}{c}{$p$} & \multicolumn{1}{c}{$d$} \\
\hline Knowing & $3.39(.43)$ & $3.37(.43)$ & 0.39 & 44 & 0.7 & 0.06 \\
Knowledge & $3.46(.58)$ & $3.67(.58)$ & -2.29 & 44 & $.03^{*}$ & -0.34 \\
\hline
\end{tabular}

$* \mathrm{p}<.05$

Hypothesis 3 tested an increase in level of openness to those who choose to live their life differently than their own cultural norms. Results were determined by examining the pre-post results from the specific question on the GPI, "I am open to people who strive to live likes very differently from my own lifestyle." A significant increase was found. Results are displayed in Table 2. 


\section{TABLE 2 \\ T-TEST RESULTS FOR PRE AND POST-TEST OF OPENNESS QUESTIONS}

\begin{tabular}{lccccc}
\hline Variable & $\begin{array}{c}\text { Pre-test } \\
\text { Mean (SD) }\end{array}$ & $\begin{array}{c}\text { Post-test } \\
\text { Mean (SD) }\end{array}$ & $t$ & $d f$ & $p$ \\
\hline $\begin{array}{l}\text { I am open to people who strive to live } \\
\text { lives very differently from my own life } \\
\text { style. }\end{array}$ & $3.87(.76)$ & $4.13(.63)$ & -2.38 & 44 & $0.02 *$ \\
\hline$* \mathrm{p}<.05$ & & & & &
\end{tabular}

\section{DISCUSSSION AND CONCLUSION}

This study sought to understand if a brief culture-shock, experiential learning, activity followed by a discussion could increase global perspective. The Global Perspective Inventory (GPI) was used as a prepost measure to determine gains in global perspective. The GPI measures three domains with two scales in each domain. In this study, the knowing scale, knowledge scale, and a specific question about openness were measured. The knowing and knowledge scales are found within the cognitive domain, and the question about openness is found in the intrapersonal domain, affect scale.

There was not an increase in the knowing scale. In fact, the mean score declined a small amount. This can be somewhat encouraging. The experiential learning activity may have allowed students to realize that they are, in-fact, not able to judge the complexity of culture context as well as they thought they could (Braskamp et al., 2014).

It is encouraging that a significant increase was found for the knowledge scale and question about openness. This significant difference shows that an activity within a fifty-minute class can increase the awareness of other cultures and the impact on the global society (Braskamp et al., 2014). Further, students who participated in the brief activity, significantly increased their openness to others who live their lives differently. This openness and awareness can allow for more respect and understanding in business situations. If one is close-minded, they may not respect or try to understand the norms of other cultures.

When individuals play BARNGA, they assume they are playing by the same rules, as all looks the same. However, this is not the case, and even small changes have a big impact. This translates to business interactions in that an individual with an underdeveloped global perspective may assume those from various cultures will follow the same business norms. This can negatively impact a business deal or a multicultural organization.

Faculty and other higher education practitioners can incorporate BARNGA in education efforts to better prepare students for the global economy. A well-developed global perspective can help students succeed in the global society. Students can understand that it is not, my country, my rules. It is a delicate balance of cultural norms and values, and those must be understood and valued for businesses to thrive.

Students do not need to travel abroad or be immersed in lengthy programs to increase their global perspective in this area. Higher education practitioners can implement this activity in various contexts ranging from classes to student organization meetings and trainings. Data has been collected a second semester, and preliminary analysis shows results consistent to this present study. Further research is needed to determine if these results are applicable in across various institutions. 


\section{REFERENCES}

Association of American Colleges and Universities. (2007). College Learning for the New Global Century: A Report from the National Leadership Council for Liberal Education and America's Promise. Washington, D. C.: Association of Colleges and Universities.

Association to Advance Collegiate Schools of Business. (2017). AACSB statement to higher education community: Stand united for more inclusive, accepting global society. Retrieved from https://www.aacsb.edu/newsroom/2017/1/aacsb-statement-to-higher-education-community-standunited-for-inclusive-accepting-global-society?_ga $=2.91046930 .98219851 .1563386543$ 13749705.1563386543

Barber, B. (2002). The educated student: Global citizen or global consumer. Liberal Education, 88(2), 2232.

Braskamp, D., Braskamp, L., \& Engberg, M. (2014). Global Perspective Inventory (GPI): Its purpose, construction, potential uses, and psychometric characteristics. Global Perspective Institute.

Braskamp, D., Braskamp, L., \& Glass, C. (2015). Belonging: The gateway to global learning for all students. Association of American Colleges and Universities, 101(3).

Casner-Lotto, J., \& Barrington, L. (2006). Are they really ready to work? Employers' perspectives on the basic knowledge and applied skills of new entrants to the $21^{\text {st }}$ century U.S. workforce. A report from the Conference Board, Inc., the Partnership for $21^{\text {st }}$ Century Skills, Corporate Voices for Working Families, and The Society for Human Resources Management.

Chhokar, J.S., Brodbeck, F.C., \& House, R.J. (2007). Culture and leadership across the world. The GLOBE book of in-depth studies in 25 societies. Erlbaum.

Cohen, S.L. (2010). Effective global leadership requires a global mindset. Industrial and Commercial Training, 4l(1), 3-10.

Earnest, G.W. (2003). Study abroad: A powerful new approach for developing leadership capacities. Journal of Leadership Education, 2(2), 46-56.

Jokinen, T. (2005). Global leadership competencies: A review and discussion. Journal of European Industrial Training, 29(3), 199-216.

Marquardt, M.J., \& Berger, N.O. (2000). Global leaders for the $21^{\text {st }}$ century. State University of New York Press.

Mendenhall, M.E., Osland, J.S., Bird, A., Oddou, G.R., \& Maznevski, M.L. (2008). Global leadership: Research, practice, and development. Routledge.

Merrill, K.C., Braskamp, L.A., \& Braskamp, D.C. (2012). Assessing individuals' global perspective. Journal of College Student Development, 53(2), 356-360. https://doi.org/10.1353/csd.2012.0034

Montgomery, J., \& Arensdorf, J. (2012). Preparing globally competent leaders through innovative study abroad experiences. Journal of Leadership Studies, 6(1). https://doi.org/10.1002/jls.21230

Moore, L.L., Boyd, B.L., Rosser, M.H., \& Elbert, C. (2009). Developing an international agricultural leadership program to meet the needs of a global community. Journal of Leadership Education, 8(1), 118-129. https://doi.org/10.12806/v8/i1/ib2

Musil, C.M. (2006). Assessing global learning: Matching good intentions with good practices. Washington, D.C.: Association of American Colleges and Universities.

Rhinesmith, S. (1996). A manager's guide to globalization: Six skills for success in a changing world (2nd ed.). McGraw Hill.

Riggio, R.E., Ciulla, J.B., \& Sorenson, G.J., (2003). Leadership education at the undergraduate level: A liberal arts approach to leadership development. In S.E. Murphy \& R.E. Riggio (Eds.), The future of leadership development (pp. 223-236). Erlbaum.

Salisbury, M.H., Umbach, P.D., Paulsen, M.B., \& Pascarella, E.T. (2009). Going global: Understanding the choice process of the intent to study abroad. Research in Higher Education, 50, 119-143.

Thiagarajan, S., \& Thiagarajan, R. (2006) BARNGA: A simulation game on cultural clashes. Nicholas Brealey Publishing. 